\title{
Evaluation And Analysis Of Debit And Pressure On Network Distribution Pdam Tirta Kahayan Kota Palangka Raya
}

\author{
Evaluasi Dan Analisis Pola Distribusi Debit Dan Tekanan Pada Jaringan Perpipaan \\ Pdam Tirta Kahayan Kota Palangka Raya
}

\author{
I Made Alit Widnyana \\ Program Studi Pendidikan Teknik Mesin, FKIP Universitas Palangka Raya \\ Kampus Unpar Tunjung Nyaho, Jl. H. Timang, 73111A
}

\begin{abstract}
PDAM Tirta Kahayan of Palangkaraya city has a technical problem regarding with inadequate service standard (coverage level). As a result from the direct observations at the service area of PDAM Tirta Kahayan of Palangka Raya city, there were numerous public complaints related to PDAM services, especially the issue on fees, debit and distributed water pressure. Lossing water in PDAM Palangka Raya City ranges from $23 \%-35 \%$. The aims of this study is to identify the condition of the pipeline distribution network of PDAM Tirta Kahayan in Palangka Raya City, to evaluate the debit distribution patterns and pressure on pipeline network of PDAM Tirta Kahayan Palangka Raya City by simulating the Epanet 2.0 program and to compare the simulation results with the exiting conditions, moreover to analyze the improvement alternatives debit and pressure on distribution piping networks. Based on the results of the simulation of Epanet 2.0 program there are still some locations that have debits and flow rates below 0.3 LPS. This is due to differences in elevation, the distance which is getting much more apart from the service source and mismatching of the pipe dimension. The improvement alternatives that have been made are by installing booster pumps in several locations that aim to increase the flow and flow velocity, continuous reservoir filling and regulation of distribution pump operation; therefore the water pressure is always maintained.
\end{abstract}

Keywords: Epanet 2.0, distribution network system, debit, pressure

PDAM Tirta Kahayan Kota Palangka Raya mempunyai masalah yaitu tingkat pelayanan (coverage level) yang rendah. Dari hasil pengamatan secara langsung di lokasi daerah layanan PDAM Tirta Kahayan Kota Palangka Raya didapatkan beberapa keluhan masyarakat mengenai layanan PDAM terutama masalah tarif, debit dan tekanan air yang terdistribusi. Kehilangan air pada PDAM Kota Palangka Raya berkisar antara 23\% -35\%. Tujuan penelitian ini adalah mengidentifikasi kondisi jaringan perpipaan distribusi PDAM Tirta Kahayan Kota Palangka Raya, mengevaluasi pola distribusi debit dan tekanan pada jaringan perpipaan distribusi PDAM Tirta Kahayan Kota Palangka Raya dengan melakukan simulasi di program Epanet 2.0 dan membandingkan hasil simulasi dengan kondisi eksiting, kemudian menganalisis alternatif perbaikan pola distribusi debit dan tekanan pada jaringan perpipaan distribusi.Berdasarkan hasil simulasi program Epanet 2.0 masih ada beberapa lokasi yang memiliki debit dan kecepatan aliran dibawah 0,3 LPS. Hal ini disebabkan karena adanya perbedaan elevasi, jarak yang semakin menjauh dari sumber layanan dan ketidaksesuaian dimensi pipa. Alternatif perbaikan yang dilakukan adalah dengan pemasangan pompa booster di beberapa lokasi yang bertujuan untuk menaikkan debit dan kecepatan aliran, pengisian reservoir secara terus menerus dan pengaturan pengoperasian pompa distribusi sehingga tekanan air selalu terjaga.

Kata Kunci: Epanet 2.0, sistem jaringan distribusi, debit, tekanan

\section{PENDAHULUAN}

Perusahaan Daerah Air Minum (PDAM) Tirta Kahayan Kota Palangka Raya sebagai Badan Usaha Milik Daerah (BUMD) milik Pemerintah Kota Palangka Raya, dibentuk berdasarkan Peraturan Pemerintah Kotamadya Daerah Tingkat II Palangka Raya Nomor 1 Tahun 1986 yang mempunyai misi menyediakan/memproduksi, mendistribusikan dan menjual air bersih yang berkualitas baik kepada masyarakat yang memenuhi standart kesehatan dan memberikan pelayanan prima kepada pelanggan maupun calon pelanggan dan tepat waktu. (http://pdam-palangkaraya.blogspot.com, 2011)
Hampir sama dengan PDAM di kota-kota lain di Indonesia, PDAM Tirta Kahayan Kota Palangka Raya juga mempunyai masalah yaitu tingkat pelayanan (coverage level) yang rendah. Dari hasil pengamatan secara langsung di lokasi daerah layanan PDAM Tirta Kahayan Kota Palangka Raya didapatkan beberapa keluhan masyarakat mengenai layanan PDAM terutama masalah tarif, debit dan tekanan air yang terdistribusi. Sebagian masyarakat mengeluhkan naiknya tarif PDAM Tirta Kahayan Kota Palangka Raya yang besarnya tidak sebanding dengan layanan yang diberikan, sebagian lainnya mengeluhkan debit dan tekanan air yang 
terdistribusikan kecil terutama pada jam jam puncak pada pagi dan sore hari, jangkauan debit dan tekanan air tidak terdistribusikan pada lokasi lokasi yang berada di ujung daerah pelayanan.

Penelitian ini bertujuan untuk mengidentifikasi kondisi jaringan perpipaan distribusi PDAM Tirta Kahayan Kota Palangka Raya, mengevaluasi pola distribusi debit dan tekanan pada jaringan perpipaan distribusi PDAM Tirta Kahayan Kota Palangka Raya dan menganalisis alternatif perbaikan pola distribusi debit dan tekanan pada jaringan perpipaan distribusi melalui evaluasi pengisian reservoir, booster, operasional pompa pada lokasi penelitian.

Penelitian ini diharapkan dapat memberikan manfaat bagi dunia pendidikan khususnya dalam pengembangan bidang ilmu rekayasa sumber daya air dengan memanfaatkan beberapa aplikasi yang ada untuk menyelesaikan masalah-masalah yang dihadapi dalam rekayasa sumber daya air dan sebagai masukan bagi PDAM Tirta Kahayan Kota Palangka Raya dalam hal mengidentifikasi kondisi jaringan perpipaan distribusi, mengevaluasi pola distribusi debit dan tekanan serta menganalisis alternatif perbaikan pola distribusi.

\section{Kajian Teori}

Faktor-faktor yang perlu mendapat perhatian dalam sistem jaringan perpipaan dalam pendistribusian air adalah tekanan, kualitas dan kontinuitas. Untuk hal tersebut perlu diperhatikan beberapa hal seperti jaringan pipa distribusi terdiri dari pipa induk, pipa cabang dan pipa servis. Yang harus diperhatikan dalam penempatan pipa distribusi adalah lokasi pipa, topografi daerah, penyebaran penduduk, ketersediaan energi gravitasi dan jumlah loop yang diperlukan. Hal ini berguna untuk mempermudah pengoperasian dan pengontrolan, serta pemerataan pipa dan pelayanan. Pemerataan pelayanan yang dimaksud adalah membuat sistem perpipaan yang sedemikian rupa sehingga seluruh kota mendapat pelayanan dengan baik.

Sistem distribusi terdiri dari 2 (dua) bagian yaitu sistem makro dan sistem mikro. Sistem makro berfungsi sebagai penghantar jaringan pipa. Jaringan pipa ini tidak boleh langsung mengalir ke konsumen karena dapat mengakibatkan penurunan energi yang sangat besar. Sistem ini disebut juga dengan sistem jaringan pipa hantar atau feeder yang terdiri dari primary feeder dan secondary feeder. Sedangkan sistem mikro berfungsi sebagai pipa pelayanan ke konsumen yaitu ke rumahrumah. Sistem mikro dapat membentuk jaringan pelayanan. Sistem mikro sering disebut sistem jaringan pipa pelayanan yang terdiri dari small distribution mains (pipa pelayanan utama), service line dan servis pipa (house connection).(Swamee, Sharma and Wiley InterScience, 2008)

Menurut Bernoulli, jumlah tinggi tempat, tinggi tekan dan tinggi kecepatan pada setiap titik dari aliran air selalu konstan. Persamaan Bernoulli dapat dipandang sebagai persamaan kekekalan energi mengingat $z$ adalah energi potensial cair tiap satuan berat.

$$
\begin{aligned}
& \frac{m \cdot g \cdot z}{m \cdot g} \approx z \\
& \frac{p}{\gamma} \approx \text { Tenaga potensial tekanan zat cair } \\
& \frac{p \cdot v}{m \cdot g} \approx p \frac{m \cdot g}{\gamma} \approx \frac{F}{\gamma} \\
& \frac{v^{2}}{2 g}=\text { tenaga kinetik } \\
& \frac{1 / 2 m \cdot v^{2}}{m \cdot g} \approx \frac{v^{2}}{2 g}
\end{aligned}
$$

Dengan neraca massa energi yang masuk sama dengan yang keluar, energi di A akan sama dengan energi di $B$, sehingga:

$$
\begin{aligned}
& H=z+\frac{p}{\gamma}+\frac{v^{2}}{2 g} \\
& z_{1}+\frac{p_{1}}{\gamma}+\frac{v^{2}}{2 g}+h f=z_{1}+\frac{p_{2}}{\gamma}+\frac{v^{2}}{2 g}+h f
\end{aligned}
$$




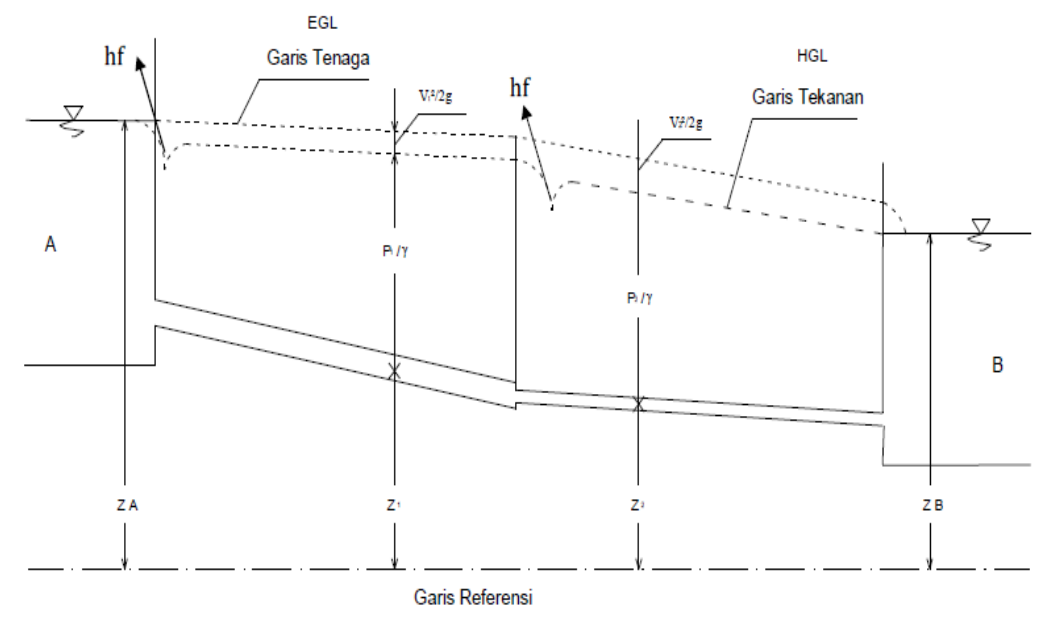

Gambar 2.1 Garis Energi dan Garis Tekanan

\section{Metode Penelitian}

Lokasi penelitian dilakukan pada PDAM Kota Palangka Raya, Kalimantan Tengah. Data yang diperlukan dala penelitian ini adalah data tekanan, data debit, jumlah pelanggan, peta jaringan, data pipa (panjang, diameter, jenis dan umur pipa), data elevasi, serta data pemakaian air. Selanjutnya membuat model jaringan dengan menggunakan software Epanet 2.0 yang kemudian dilakukan input data dan model disimulasikan. Setelah itu, dilakukan kalibrasi dan validasi data untuk membandingkan data observasi dengan hasil simulasi jaringan. Peta lokasi penelitian dapat dilihat pada Gambar 3.1 berikut:

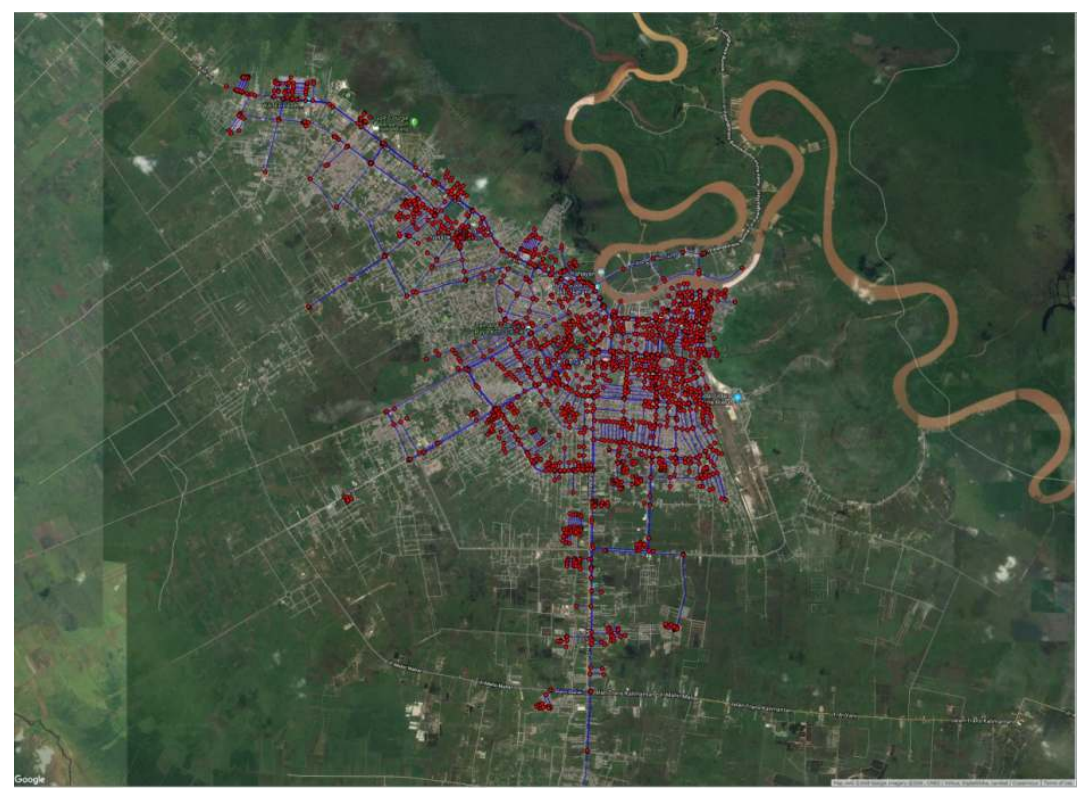

Gambar 3.1 Lokasi Penelitian PDAM Kota Palangka Raya

\section{Hasil dan Pembahasan}

Air baku PDAM Kota Palangka Raya diambil dari sumber air Sungai Kahayan yang mempunyai kuantitas debit sebesar 3.727,5 liter/detik. Kapasitas IPA sebesar 217,5 Liter/detik yang dibangun pada tahun 1997/1997. Pada unit distribusi, reservoir distribusi mempunyai kapasitas $2.500 \mathrm{~m}^{3}$. Sistem pengaliran menggunakan 2 (dua) pompa distribusi masing-masing mempunyai kapasitas $120 \mathrm{~L} /$ det dan $150 \mathrm{~L} /$ det dimana pompa dengan kapasitas $120 \mathrm{~L} /$ det beroperasi secara terus menerus dan pompa dengan kapasitas 150 L/det hanya beroperasi pada jam jam puncak pagi dan sore hari. Sistem perpipaan menggunakan sistem cabang melalui pipa jenis PVC dan sebagian kecil pipa jenis HDPE dengan diameter pipa dari $\varnothing 500 \mathrm{~mm}-\varnothing 63 \mathrm{~mm}$. Jumlah pelanggan sampai akhir tahun 2017 sebanyak 17.286 pelanggan tersebar di 4 (empat) lokasi kecamatan.

Elevasi di wilayah Kota Palangka Raya tidak terdapat perbedaan yang besar karena wilayah Kota Palangka Raya relatif datar. Data elevasi berkisar antara 
49,00 - 51,69 m.dpl (meter diatas permukaan laut). Data counter plot dari elevasi lokasi jaringan perpipaan jika disandingkan dengan data tekanan di masing-masing junction (node) menunjukkan bahwa elevasi dari suatu lokasi berbanding terbalik dengan tekanan pada lokasi tersebut. Semakin besar elevasi dari suatu lokasi maka tekanan pada lokasi tersebut semakin kecil demikian juga sebaliknya.

Rentang tekanan pada sistem jaringan distribusi berkisar diantara 106,52 - 120,12 mka dimana tekanan terendah sebesar 106,52 mka terjadi pada node 1690 yang berjarak $\pm 9 \mathrm{~km}$ dari pusat layanan dan tekanan tertinggi sebesar 120,12 mka terjadi pada node 1052 yang berjarak $\pm 2,4 \mathrm{~km}$ dari pusat layanan. Nilai rentang tekanan tersebut sudah memenuhi standar tekanan air oleh Peraturan Menteri Pekerjaan Umum Nomor 18 Tahun 2007 (Permen PU No. 18 Tahun 2017).

Ditinjau dari hasil data link pada simulasi program Epanet 2.0 didapatkan ada beberapa kecepatan air dalam pipa yang tidak memenuhi standar kecepatan aliran dalam pipa (0,3-4,5 liter/detik) sesuai Permen PU No. 18 Tahun 2007. Hal ini disebabkan oleh sistem pengaliran yang belum optimal karena beberapa faktor diantaranya desain perpipaan yang kurang efektif, debit distribusi yang belum mencukupi, serta adanya peningkatan kebutuhan air yang tinggi melebihi kapasitas desain perpipaan awal.

Besarnya rentang debit yang terdistribusi pada sistem jaringan PDAM Kota Palangka Raya adalah 0,01 26,85 Liter/detik (LPS). Nilai debit terbesar berada pada jaringan yang sangat dekat dengan pusat layanan, sedangkan debit dengan nilai kecil berada pada jaringan yang jauh dari pusat layanan.

Tekanan diukur pada beberapa lokasi yang dianggap mewakili sebagai titik - titik kritis, adapun alat yang dipergunakan adalah pressure recorder. Hasil pengukuran dapat dilihat pada Tabel 4.1 berikut:

Table 4.1 Hasil Pengukuran Tekanan

\begin{tabular}{|c|c|c|c|c|c|c|c|c|c|c|c|c|c|}
\hline \multirow{3}{*}{ Pukul } & \multicolumn{13}{|c|}{ Tekanan (mka) } \\
\hline & \multicolumn{13}{|c|}{ Pada Elevasi (mdpl) } \\
\hline & 48.71 & 49.40 & 49.68 & 50.00 & 50.46 & 49.81 & 49.84 & 49.66 & 49.71 & 50.26 & 51.55 & 51.66 & 49.66 \\
\hline 01.00 & 4.90 & 9.81 & 9.98 & 10.00 & 10.00 & 1.00 & 2.90 & 11.77 & 1.00 & 2.94 & 7.85 & 4.90 & 4.80 \\
\hline 02.00 & 4.90 & 9.81 & 9.80 & 10.00 & 10.00 & 1.00 & 2.90 & 11.77 & 1.00 & 2.94 & 7.85 & 4.90 & 4.80 \\
\hline 03.00 & 4.90 & 9.81 & 9.80 & 10.00 & 10.00 & 1.00 & 2.90 & 11.77 & 1.00 & 2.94 & 7.85 & 4.90 & 4.80 \\
\hline 04.00 & 4.90 & 9.81 & 9.80 & 10.00 & 10.00 & 1.00 & 2.90 & 11.77 & 1.00 & 2.94 & 7.85 & 4.90 & 10.80 \\
\hline 05.00 & 10.90 & 15.81 & 15.80 & 16.00 & 10.00 & 1.00 & 8.90 & 11.77 & 1.00 & 8.94 & 13.85 & 10.90 & 10.80 \\
\hline 06.00 & 10.90 & 15.81 & 15.80 & 16.00 & 10.00 & 1.00 & 8.90 & 11.77 & 1.00 & 8.94 & 13.85 & 10.90 & 10.80 \\
\hline 07.00 & 10.90 & 15.81 & 15.80 & 16.00 & 10.00 & 1.00 & 8.90 & 11.77 & 1.00 & 8.94 & 13.85 & 10.90 & 10.80 \\
\hline 08.00 & 10.90 & 15.81 & 15.80 & 16.00 & 10.00 & 1.00 & 8.90 & 11.77 & 1.00 & 8.94 & 13.85 & 10.90 & 10.80 \\
\hline 09.00 & 10.90 & 15.81 & 15.80 & 16.00 & 10.00 & 1.00 & 8.90 & 11.77 & 1.00 & 8.94 & 13.85 & 10.90 & 4.90 \\
\hline 10.00 & 4.90 & 9.81 & 9.80 & 10.00 & 10.00 & 1.00 & 2.90 & 11.77 & 1.00 & 2.94 & 7.85 & 4.90 & 4.90 \\
\hline 11.00 & 9.48 & 9.81 & 9.80 & 10.00 & 10.00 & 1.00 & 2.90 & 11.77 & 1.00 & 2.94 & 7.85 & 4.90 & 4.90 \\
\hline 12.00 & 4.80 & 9.81 & 9.80 & 10.00 & 10.00 & 1.00 & 2.90 & 11.77 & 1.00 & 2.94 & 7.85 & 4.90 & 4.90 \\
\hline 13.00 & 4.80 & 9.81 & 9.81 & 10.00 & 10.00 & 1.00 & 2.90 & 11.77 & 1.00 & 2.94 & 7.85 & 4.90 & 6.90 \\
\hline 14.00 & 6.80 & 11.81 & 11.98 & 12.00 & 10.00 & 1.00 & 4.90 & 13.77 & 1.00 & 4.94 & 9.85 & 6.90 & 5.90 \\
\hline 15.00 & 5.80 & 10.81 & 10.98 & 11.00 & 10.00 & 1.00 & 3.90 & 12.77 & 1.00 & 3.94 & 8.85 & 5.90 & 9.90 \\
\hline 16.00 & 9.80 & 14.81 & 14.98 & 15.00 & 7.50 & 1.00 & 7.90 & 16.77 & 1.00 & 7.94 & 12.85 & 9.90 & 9.90 \\
\hline 17.00 & 9.80 & 14.81 & 14.98 & 15.00 & 10.00 & 1.00 & 7.90 & 16.77 & 1.00 & 7.94 & 12.85 & 9.90 & 9.90 \\
\hline 18.00 & 9.80 & 14.81 & 14.98 & 15.00 & 11.00 & 1.00 & 7.90 & 16.77 & 1.00 & 7.94 & 12.85 & 9.90 & 9.90 \\
\hline 19.00 & 9.80 & 14.81 & 14.98 & 15.00 & 10.00 & 1.00 & 7.90 & 16.77 & 1.00 & 7.94 & 12.85 & 9.90 & 6.90 \\
\hline 20.00 & 6.80 & 11.81 & 11.98 & 12.00 & 12.50 & 1.00 & 4.90 & 13.77 & 1.00 & 4.94 & 9.85 & 6.90 & 4.90 \\
\hline 21.00 & 4.80 & 9.81 & 9.98 & 10.00 & 9.00 & 1.00 & 2.90 & 11.77 & 1.00 & 2.94 & 7.85 & 4.90 & 4.90 \\
\hline 22.00 & 4.80 & 9.81 & 9.98 & 10.00 & 8.00 & 1.00 & 2.90 & 11.77 & 1.00 & 2.94 & 7.85 & 4.90 & 4.90 \\
\hline 23.00 & 4.80 & 9.81 & 9.98 & 10.00 & 8.00 & 1.00 & 2.90 & 11.77 & 1.00 & 2.94 & 7.85 & 4.90 & 4.90 \\
\hline 24.00 & 4.80 & 9.81 & 9.98 & 10.00 & 8.00 & 1.00 & 2.90 & 11.77 & 1.00 & 2.94 & 7.85 & 4.90 & 4.90 \\
\hline
\end{tabular}

Berdasarkan hasil pengukuran dibeberapa lokasi wilayah PDAM Kota Palangka Raya didapatkan hasil sesuai dengan Tabel 4.1 diatas dapat dilihat tekanan pada beberapa titik lokasi pengukuran memiliki nilai yang berbeda tergantung dari jarak lokasi dengan sumber Jurnal Pendidikan Teknologi dan Kejuruan BALANGA ISSN 2338-426X utama layanan dan perbedaan elevasi sesuai dengan lokasi penelitian. Titik pantau 6,7,9 dan 10 lokasinya berjarak 5 kilometer $(\mathrm{km})$ dari pusat layanan dan elevasinya lebih dari 50 m.dpl yang memiliki tekanan kurang dari 10 mka. Titik pantau 6 berada di Jl. Sepakat 
komplek Bangas Permai Kota Palangka Raya mempunyai tekanan rendah karena pipa induk melewati lokasi yang mempunyai elevasi yang tinggi sehingga tekanan air menjadi turun pada lokasi tesebut. Sedangkan titik pantau 9 lokasinya berada sejauh $12 \mathrm{~km}$ dari pusat layanan memiliki tekanan rendah kurang dari 10 mka. Dibeberapa titik pantau tekanan yang terukur justru naik pada saat jam-jam puncak yaitu pukul $06.00-08.00$ dan pukul 17.00 - 19.00, ini disebabkan karena penggunaan pompa distribusi dimana pada jam-jam tersebut pompa distribusi yang beroperasi memakai 2 (dua) unit sehingga membantu terjadinya kenaikan tekanan.

\subsection{Kalibrasi Data}

Hasil pembacaan pressure recorder pada Gambar 4.1 menunjukkan setelah dilakukan kalibrasi dengan pengambilan sampel tekanan pada 13 di lokasi penelitian didapatkan nilai korelasi $69,5 \%$. Parameter yang dijadikan variabel untuk kalibrasi adalah head pompa. Dalam hasil perhitungan Epanet 2.0 dengan data yang terukur di lapangan perbandingannya sudah mendekati. Ada beberapa faktor yang membuat nilai korelasi belum $100 \%$ diantaranya dikarenakan umur dari jaringan perpipaan yang digunakan akan berpengaruh pada koefisien Hazen William semakin tua umur pipa maka kekasaran

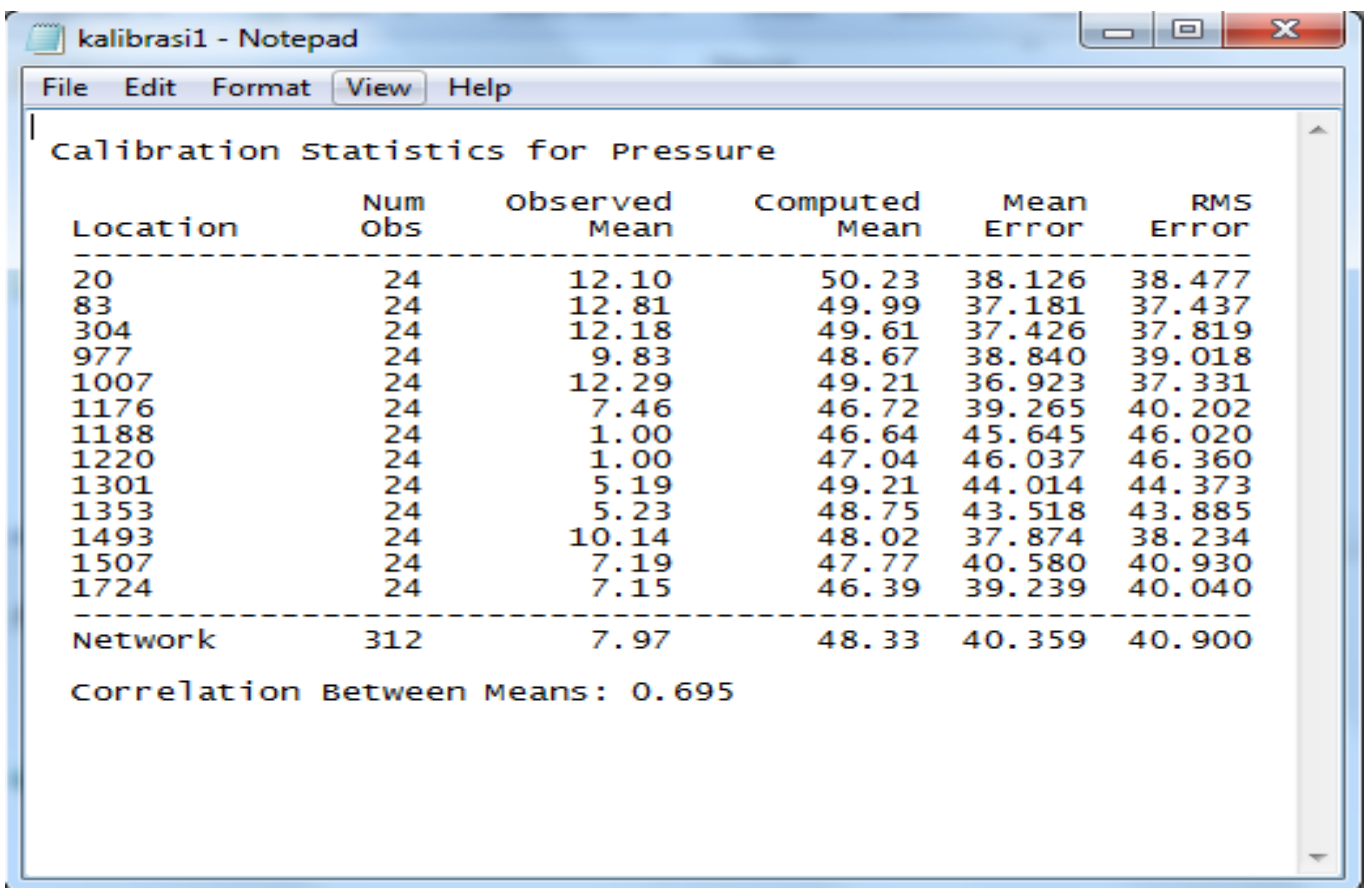

Gambar 4.1 Hasil Kalibrasi Tekan

\subsection{Validasi Debit}

Pengukuran debit secara langsung di lapangan pada beberapa titik pantau yang dianggap mewakili kondisi seluruh jaringan, perlu juga dibuktikan dengan cara validasi data hasil perhitungan Epanet 2.0 dengan pengukuran dilapangan untuk diperoleh hasil mendekati keadaan sebenarnya di lapangan. Hasil validasi dari simulasi model Epanet 2.0 dilakukan untuk mengetahui keakuratan hasil simulasi Epanet 2.0 dengan data yang terukur dilapangan.

\subsection{Simulasi Pola Sebaran Tekanan}

Berdasarkan hasil simulasi pada Gambar 4.2 semua node pada sistem jaringan sudah memenuhi standar tekanan. Tekanan sangat dipengaruhi oleh elevasi, jarak dan head pompa, semakin menjauhi sumber air maka tekanan akan semakin kecil karena adanya energi friksi (pengurangan energy karena adanya gesekan) antara air dengan pipa. 


\begin{tabular}{|l|}
\hline Pressure \\
121.93 \\
122.47 \\
122.72 \\
122.88 \\
12.88 \\
\hline \hline \\
\hline Flow \\
0.04 \\
0.08 \\
0.19 \\
0.19 \\
0.63 \\
\hline LPS \\
\hline
\end{tabular}

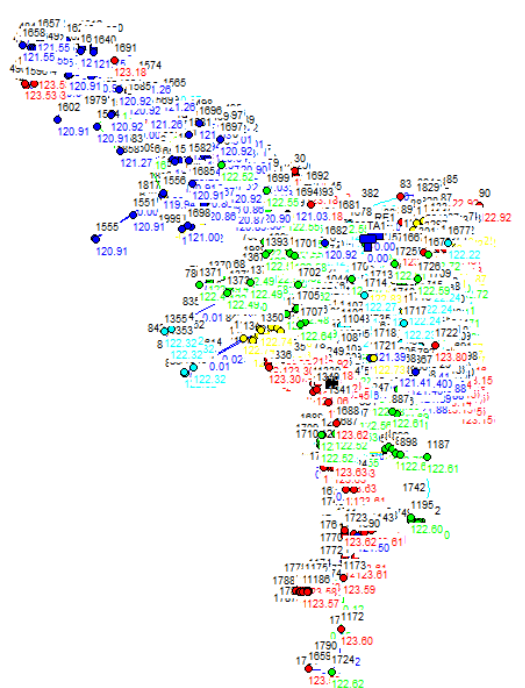

\section{Gambar 4.2 Simulasi Tekanan Pada Jam Puncak}

\subsection{Alternatif Perbaikan}

Alternatif perbaikan adalah pemasangan pompa booster dibeberapa tempat dimana tempat tersebut mempunyai kecepatan aliran kurang dari 0,3 liter/detik. Pompa booster ini mempunyai spesifikasi debit 60 liter/detik dan head 3 meter. Pompa ini dipasang di beberapa lokasi dengan pertimbangan-pertimbangan dari segi kemudahan pemasangan, tempat dan keamanan jaringan. Setelah dipasang beberapa booster di beberapa lokasi terdapat perubahan pada jaringan seperti terlihat pada Tabel 4.2 dibawah ini:

Tabel 4.2 Alternatif Perbaikan

\begin{tabular}{|c|c|c|c|c|}
\hline Indikator Perbaikan & $\begin{array}{l}\text { Kondisi } \\
\text { Sekarang }\end{array}$ & $\begin{array}{l}\text { Penambahan } \\
\text { Booster }\end{array}$ & $\begin{array}{c}\text { Penambahan } \\
\text { Dimensi } \\
\text { Reservoir }\end{array}$ & $\begin{array}{c}\text { Perubahan } \\
\text { waktu } \\
\text { operasional } \\
\text { pompa distribusi }\end{array}$ \\
\hline Rentang tekanan di jaringan distribusi & $\begin{array}{c}106,52- \\
120,12 \mathrm{mka}\end{array}$ & $\begin{array}{c}105,7- \\
120,25 \mathrm{mka}\end{array}$ & $\begin{array}{c}105,7- \\
120,25 \mathrm{mka}\end{array}$ & $\begin{array}{c}105,7-120,25 \\
\mathrm{mka}\end{array}$ \\
\hline $\begin{array}{l}\text { Jumlah node yang berada di atas } \\
\text { standar tekanan }\end{array}$ & 1727 & 1727 & 1727 & 1727 \\
\hline $\begin{array}{l}\text { Jumlah node yang berada dibawah } \\
\text { standar tekanan }\end{array}$ & 0 & 0 & 0 & 0 \\
\hline Rentang debit di jaringan distribusi & $0-71,88$ & $0-102,73$ & $0-108,76$ & $0-108,76$ \\
\hline $\begin{array}{l}\text { Jumlah link yang berada di atas standar } \\
\text { debit }\end{array}$ & 103 & 497 & 496 & 496 \\
\hline $\begin{array}{l}\text { Jumlah link yang berada di bawah } \\
\text { standar debit }\end{array}$ & 1909 & 1525 & 1525 & 1525 \\
\hline $\begin{array}{l}\text { Rentang kecepatan aliran di jaringan } \\
\text { distribusi }\end{array}$ & $0-0,37$ & $0-10,81$ & $0-10,81$ & $0-10,81$ \\
\hline $\begin{array}{l}\text { Jumlah link yang berada di atas standar } \\
\text { kecepatan aliran }\end{array}$ & 1 & 67 & 67 & 67 \\
\hline $\begin{array}{l}\text { Jumlah link yang berada di bawah } \\
\text { standar kecepatan aliran }\end{array}$ & 2011 & 1955 & 1955 & 1955 \\
\hline Keperluan energy listrik & 104,44 & 119,74 & 119,74 & 119,74 \\
\hline Biaya listrik & $250.636,60$ & $4.216 .552,00$ & $4.216 .552,00$ & $4.216 .552,00$ \\
\hline
\end{tabular}

\section{Kesimpulan dan Saran \\ Kesimpulan}

Kesimpulan yang dapat diambil dari penelitian yang telah dilakukan adalah sebagai berikut:
1. Sistem pengaliran menggunakan 2 (dua) pompa distribusi masing-masing mempunyai kapasitas 120 L/det dan 150 L/det dimana pompa dengan kapasitas $120 \mathrm{~L} /$ det beroperasi secara terus menerus 
dan pompa dengan kapasitas 150 L/det hanya beroperasi pada jam jam puncak pagi dan sore hari, dengan sistem cabang melalui pipa jenis PVC dengan diameter pipa dari $\varnothing 500 \mathrm{~mm}-\varnothing 63 \mathrm{~mm}$.

2. Nilai tekanan air pada jam puncak di pagi hari jam 06.00 pagi hari dan jam 18.00 pada sore hari di seluruh wilayah layanan PDAM Kota Palangka Raya berkisar antara 106,52 sampai dengan 120,12 mka (meter kolom air) nilai tersebut sudah memenuhi standar tekanan air

3. Nilai tekanan sangat berpengaruh pada tinggi elevasi, jarak reservoir ke pelanggan dan kebutuhan air pada pelanggan.

4. Pemasangan pompa booster dibeberapa tempat mampu menaikkan debit dan kecepatan aliran di beberapa lokasi yang berada di bawah standar.

\section{Saran}

Saran yang dapat diberikan adalah sebagai berikut:

1. Pipa berjenis PVC sebaiknya segera diganti menjadi pipa jenis HDPE karena pipa berjenis PVC masih kurang baik untuk pendistribusian air minum.

2. Untuk meminimalisir besarnya tekanan yang ada maka perlu dilakukan pemasangan Preasure Reducing Valve (PRV) sebelum meter induk diawal jaringan.

3. Penelitian selanjutnya diharapkan agar bisa memasukkan aksesoris seperti valve, VCD dan PRV pada model jaringan distribusi pada Epanet 2.0 agar hasil simulasi bisa lebih baik lagi.

\section{DAFTAR PUSTAKA}

[1]. Anonim, Departemen Pekerja Umum. (2007). Peraturan Menteri Pekerjaan Umum No: 18/PRT/M/2007. Pedoman Penyusunan Perencanaan Teknis Pengembangan Sistem Penyediaan Air Minum. Departemen Pekeja Umum: Jakarta.

[2]. Anonim, PDAM Tirta Kahayan Kota Palangka Raya. Peta Jaringan Perpipaan Distribusi. Palangka Raya

[3]. Ardiansyah, Juwono, P. T., \& Ismoyo, M. J. (2012). Analisa Kinerja Sistem Distribusi Air Bersih Pada PDAM di Kota Ternate. Jurnal Teknik Pengaliran, 3(2), 211-220. Mahasiswa Program Magister Teknik Pengaliran. Universitas Brawijaya.

[4]. Haq, B., \& Masduqi, A. (2014). Sistem Distribusi Air Siap Minum PDAM Kota Malang: Studi Kasus
Kecamatan Blimbing. Jurnal Teknik Pomits, 3(2), 2337-3539.

[5]. Idris, F., Azmeri, \& Ziana. (2012). Analisa Kinerja Jaringan Distribusi Air Bersih di Perumnas Lingke Kecamatan Syiah Kuala Kota Banda Aceh. Jurnal Teknik Sipil, 1(1), 122.

[6]. Krisnayanti, D. S., Udiana, I. M., \& Benu, J. H. (2013). Studi Perencanaan Pengembangan Penyediaan Air Bersih di Kecamatan Kupang Timur Kabupaten Kupang. Jurnal Teknik Sipil, II(1), Jurusan Teknik Sipil Fakultas Sains dan Teknik. Universitas Nusa Cendana.

[7]. Natalia, B. M., Mardiyono, \& Said, A. (2012). Implementasi Program Zona Air Minum Prima (ZAMP) untuk Memenuhi Kebutuhan Air Minum Masyarakat (Studi pada PDAM Kota Malang). Jurnal Administrasi Publik (JAP), 2(1), 11-15.

[8]. Paryono, \& Susilo, H. (2014). Analisa Jaringan Distribusi Air PDAM Giri Tirta Sari (Studi Kasus Perumahan Griya Bulusulur Permai Wonogiri). Jurnal Tugas Akhir, Jurusan Teknik Sipil Fakultas Teknik. Universitas Mercu Buana Jakarta.

[9]. Pasaribu, S. E. (2005). Zona Air Minum Prima (ZAMP). Jurnal Sistem Teknik Industri, 6(2).

[10]. Pekuwali, U. L., Indaryanto, H. W., \& Masduqi, A. (2005). Evaluasi Dan Rencana Pengembangan Sistem Distribusi Air Bersih di Kecamatan Kota Waingapu Kabupatenn Sumba Timur. Jurnal Purifikasi, 6(2), 109-114.

[11]. Rivai, Y., Masduki, A., \& Marsono, B. D. (2006). Evaluasi Sistem Distribusi dan Rencana Peningkatan Pelayanan Air Bersih PDAM Kota Gorontalo. Jurnal SMARTek, 4(2), 126-134.

[12].Safii, A. (2012). Evaluasi Jaringan Sistem Penyediaan Air Bersih di PDAM Kota Lubuk Pakam. Tugas Akhir Fakultas Teknik, Universitas Sumatera Utara.

[13]. Suyitno, B. (2008). Evaluasi Hidrolis dan Sisa Klor Pada Jaringan Pipa Eksisting Zona Air Minum Prima Dengan Simulasi Epanet 2.0 Di PDAM Kota Malang. Laporan Kerja Praktik Lapangan, Program Studi Teknik Lingkungan Akademi Teknik Tirta Wiyata Magelang.

[14].Syahputra, B. (2005). Pengaruh Penambahan Debit Kebutuhan pada Zona Pelayanan Air Bersih di PDAM Tirta Meulaboh. Jurnal Pondasi, 11(1)PDAM Tirta Meulaboh. Jurnal Pondasi, 11(1) 